\title{
Analisis Prioritas Pemilihan Produk-Produk Halal pada Masyarakat Muslim Kelas Menengah
}

\author{
Hanny Nurlatifah ${ }^{1}$,Bambang Eko Samiono ${ }^{1}$, Shohibul Imam ${ }^{1}$ \\ ${ }^{1}$ Program studi manajemen,Fakultas Ekonomi dan Bisnis, Universitas Al Azhar Indonesia, \\ Jl Singgamangaraja, Kompleks Masjid Agung Al Azhar, Kebayoran Baru, Jakarta Selatan, 12110 \\ Penulis untuk Korespondensi/E-mail: hanny@uai.ac.id
}

\begin{abstract}
The purpose of writing this article is to map the product selection priorities in the Muslim community in the middle class as the object of research. The method used is a Focus Group Discussion involving Middle-class society and students. The analytical tool used is Interpretive structural modeling (ISM). Food and beverage but a top priority for all consumers in all categories. Travel has received more attention from consumers. Muslim-friendly travel could be the next tren.
\end{abstract}

Keyword: Consumer behavior; Halal products; Muslim consumers

\begin{abstract}
Abstrak
Tujuan penulisan artikel ini adalah melakukan pemetaan prioritas pemilihan produk pada masyarakat muslim di kelas menengah sebagai objek penelitian. Metode yang digunakan adalah Diskusi kelompok yang melibatkan masyarakat umum, dan mahasiswa. Alat analisis yang digunakan adalah Permodelan menggunakan Interpretative Structural Modelling. Hasil yang didapatkan terdapat perbedaaan pola pengambilan keputusan berdasarkan jenis kelamin dan usia konsumen. Makanan dan minuman tetapi menjadi prioritas utama bagi seluruh konsumen di seluruh kategori. Perjalanan wisata telah mendapat perhatian lebih dari konsumen. Perjalanan wisata yang ramah untuk muslim dapat menjadi tren selanjutnya
\end{abstract}

Kata kunci: Konsumen muslim; Produk halal; Perilaku konsumen

\section{PENDAHULUAN}

The Global Islamic Economy Indicator (GIEI) yang merupakan ukuran bagi kekuatan suatu negara secara relatif untuk mendukung sektor perekonomian islami (makanan halal, keuangan islami, wisata Islam, wisata halal, Fashion, Farmasi halal serta kosmetika halal) Indonesia menempati urutan ke 5 (skor 49) dengan Malaysia (skor 111) dan UAE (skor 79) pada urutan pertama dan kedua, (State of the Global Islamic Economy Report, 2019) Penduduk muslim di Indonesia berdasarkan sensus penduduk 2010 sebesar 87,18\%, dengan kata lain memiliki potensi dalam jumlah yang cukup besar namun dikarenakan posisi Indonesia dalam kancah perekonomian Islam belum memiliki peranan yang signifikan. Permasalahan menjadi dasar dari penelitian ini adalah kondisi Indonesia yang secara jumlah penduduk muslim unggul tapi belum mampu memberikan kontribusi yang berarti bagi perkembangan perekonomian Islam di Indonesia maupun perekonomian negara. Jumlah produk yang memiliki label halal periode tahun 2021 sampai dengan tahun 2019 sebanyak 894.794 produk. Angka tersebut baru mencapai $10 \%$ dari keseluruhan produk yang 
beredar di Indonesia. (MUI, 2019) Kewajiban untuk produsen untuk memiliki label halal untuk produk yang beredar telah diatur dalam UU No. 33 Tahun 2014, namun implementasi yang belum optimal diduga sebagai penyebab rendahnya anggak produk dengan label halal MUI. Tantangan terbesar saat ini sebenarnya terjadi pada sisi konsumen. Kesadaran konsumen yang rendah terhadap keberadaan produk halal memberikan kontribusi terhadap keengganan produsen untuk menjadikan produknya memiliki label halal MUI. Untuk itu penting mengetahui untuk memahami prioritas pola pembelian produk halal dari sisi konsumen. Berdasarkan latar belakang di atas dirumuskan Tujuan penulisan artikel ini yaitu mengetahui pola prioritas pemilikan produk bersertifikat halal konsumen muslim. "Kajian tentang tentang Purchacse Intention (keputusan pembelian) telah dilakukan oleh beberapa penelitian terdahulu. Atittude, Subjective Norm, Percived behavioral Control, Environmental ethics dan environmental Awareness merupakan variabel yang dikonstruksikan akan memiliki pengaruh terhadap Purchase Intentions produk produk ramah lingkungan. Penempatan variabel tersebut ditujukan untuk mengetahui penerapan teori Plannned behavior terhadap tingkat kesadaran terhadap lingkungan dan kepercayaan dan etik yang berlaku. (Haque, Sarwar, Yasmin, Tarofder, \& Hossain, 2015)

Faktor -faktor yang mempengaruhi Gen Z Muslim Malaysia dalam memilih makanan lebih condong pada ketertarikan mereka terhadap makanan dan tidak peduli terhadap tingkat halal makanan tersebut. (Bashir, 2019) (Krishnan, Amira, Atilla, Syafawani, \& Hafiz, 2017). Kajian lainnya judul The Role of Halal Awareness and Halal Certification in Influencing Purchase Intentions, menunjukkan hasil variabel Halal Awareness, food Quality, Marketing Promotion dan merek memiliki pengaruh langsung terhadap keputusan pembelian hanya variabel Halal certification yang tidak memiliki pengaruh terhadap Purchase Intentions pada komunitas konsumen Non Muslim di Malaysia, (Chandan A, 2019).

Terlihat dari penelitian- penelitian di atas bahwa kepercayaan terhadap nilai-nilai yang dianut oleh seseorang memiliki pengaruh terhadap pengambilan keputusan konsumen. Kekuatan nilai-nilai yang dianut seseorang selain memiliki pengaruh langsung terhadap keputusan pembelian juga menjadi faktor yang mempengaruhi ke kekuatan merek suatu produk namun variabel halal awarenens masih belum memiliki pengaruh yang signifikan terhadap keputusan pembelian produk/jasa. Untuk itu tujuan dari penulisan artikel ini adalah melakukan pemetaan prioritas pemilihan produk pada masyarakat muslim di kelas menengah sebagai objek penelitian. Kelas ini menjadi sasaran karena merupakan tulang punggung penggerak industri produk halal khususnya di Indonesia. Pengetahuan tersebut akan dapat digunakan sebagai dasar pembentukan strategi dan pola kebijakan untuk menggiatkan pasar produk halal di Indonesia. Pembentukan motivasi dalam seseorang dapat dijelaskan oleh model motivasi (Al-Kwifi, Farha, \& ahmed, 2019), dimana model tersebut menggambarkan bahwa stimulus atau rangsangan akan menyebabkan pengenalan kebutuhan. Rangsangan akan terjadi apabila ada kesenjangan dari apa yang dirasakan dengan apa yang seharusnya dirasakan. Kesenjangan ini yang akan menimbulkan kebutuhan. Ketika seseorang sudah sadar atas kebutuhannya makan akan muncul tekanan dari dirinya untuk melakukan suatu tindakan. Faktor biaya atau pengorbanan merupakan faktor yang selalu dihadapi oleh konsumen untuk memutuskan sumber daya yang akan dikeluarkan dan seberapa penting produk yang dibutuhkan dan diinginkan. Oleh karena itu, konsumen akan dihadapkan pada persoalan motivasi atau pendorong. Motivasi konsumen adalah keadaan di dalam pribadi seseorang yang mendorong keinginan individu untuk melakukan kegiatan guna mencapai suatu tujuan. Ada lima tujuan Motivasi Konsumen yaitu meningkatkan kepuasan, mempertahankan loyalitas, efisiensi, efektivitas dan mencipta suatu hubungan yang harmonis antara produsen atau penjual dan pembeli atau konsumen, (Niazi, Ghani, \& Aziz, 2019). Teori perilaku konsumen yang bisa menjadi dasar lain untuk membentuk motivasi seseorang bertindak adalah Theory of Planned Behavior (TPB) merupakan pengembangan dari Theory of Reasoned Action (TRA) yang berkembang pada tahun 1967 . Teori ini didasari pada asumsi bahwa manusia biasanya akan berperilaku pantas (behave in a sensible manner). Manusia biasanya berperilaku dengan cara yang masuk sebelum sesuatu diputuskan akan memikirkan dampak dari keputusan tersebut. Kerangka untuk mempelajari sikap seseorang terhadap perilakunya. Faktor 
terpenting adalah intensi untuk berperilaku yang merupakan kombinasi dari sikap untuk menampilkan perilaku tersebut dan norma subjektif. Sikap individu terhadap perilaku meliputi kepercayaan mengenai suatu perilaku, evaluasi terhadap hasil perilaku, norma subjektif, kepercayaan-kepercayaan normatif dan motivasi untuk patuh. Sikap dan norma subjektif diukur dengan skala (misalnya skala Likert/skala rating) menggunakan frase suka/tidak suka, baik/buruk, dan setuju/tidak setuju. Intensi untuk menampilkan suatu perilaku tergantung pada hasil pengukuran sikap dan norma subjektif. Hasil yang positif mengindikasikan intensi berperilaku dengan model di bawah ini. (Wang, Wong, \& Narayan, The demographic impact of consumer green purchase intention toward Green Hotel Selection in China, 2019).

Kunci dari positioning adalah citra produk atau jasa yang ingin dilihat oleh konsumen. Fokus utama dari positioning adalah persepsi konsumen terhadap suatu produk maupun suatu kegiatan. Teori motivasi dapat menjadi pijakan produsen atau pengelola usaha untuk menentukan positioning produknya yang diinginkan oleh konsumen. (Amalia, Sosianika, $\&$ Suharto, 2020)

\section{METODE PENELITIAN}

Metode yang digunakan adalah Focus Group Discussion yang melibatkan masyarakat umum, dan mahasiswa. dan mahasiswa. Diskusi 12 sampel yang terdiri kategori usia 17-25 tahun sebagai kategori dewasa muda dan usia 25 tahun ke atas sebagai kategori dewasa. Alat analisis yang digunakan adalah Interpretative Structural Modelling (ISM) adalah proses pembelajaran interaktif klasik yang mengubah model formulasi dasar menjadi yang terdefinisi dengan jelas dan terfokus. ISM merupakan metodologi untuk mengidentifikasi hubungan di antara item spesifik yang menentukan masalah atau sub masalah. ISM berkonsentrasi pada merusak sistem yang rumit menjadi beberapa sub sistem sederhana dan memberikan pemahaman mendasar tentang situasi yang kompleks, serta untuk menyusun tindakan untuk memecahkan masalah. ISM banyak digunakan dalam rumusan strategi bisnis yang bersifat operasional (Fadhil et al.2018). ISM adalah salah satu teknik permodelan untuk kebijakan strategis. Teknik
ISM terkait dengan interpretasi objek utuh atau representasi sistem secara sistematis dan aplikasi teori grafik berulang (J. P. Saxena; Sushil; Prem Vrat, 1992). ISM adalah sebuah proses transformasi model. Dalam penelitian ini, ISM digunakan untuk merumuskan hierarki keputusan konsumen dalam pemilihan produk yang bersertifikasi halal. Pengolahan data prioritas menggunakan software EXIMPRO. permodelan Interpretive Structural Modelling (ISM)). (Marimin, 2010) Permodelan ini dilakukan dengan langkah-langkah yang disampaikan secara ringkas sebagai berikut:

1) Melakukan identifikasi di dalam sistem dan didaftarkan. Elemen-elemen tersebut dikumpulkan melalui penelitian, diskusi dan cara-cara lain

2) Menetapkan hubungan kontekstual antar elemen berdasarkan tujuan permodelan

3) Matriks Interaksi tunggal (Structural Self Interaction Matrix-SSIM) dibentuk berdasarkan persepsi dan penilaian responden yang dalam penelitian ini adalah pakar yang terkait dengan UMKM. Hubungan antar elemen, yaitu elemen 1 (Ei) dan elemen 2 (Ej) disimbolkan dalam empat tipe penilaian yang diwakilkan dengan simbol huruf VAXO dengan keterangan sebagai berikut:

a. V apabila elemen 1 mempengaruhi elemen 2, tetapi tidak sebaliknya

b. A apabila elemen 2 mempengaruhi elemen 1 , tidak sebaliknya.

c. $X$ apabila elemen 1 dan elemen 2 saling mempengaruhi.

d. O apabila elemen 1 dan elemen 2 tidak saling mempengaruhi

4). Transformasi SSIM menjadi Reachability (RM) dengan mengonversi menjadi matriks biner, dimana bila sesuatu elemen mempengaruhi elemen lain yang diberikan angka 1 dan bila suatu elemen tidak mempengaruhi elemen lain diberikan angka 0 . Setelah itu akan dihasilkan masing-masing simbol menjadi $\mathrm{V}(1,0), \mathrm{A}$ $(0,1), X(1,1)$ dan $\mathrm{O}(0,0)$. Selanjutnya dari hasil RM akan dihasilkan nilai Driver Power (DP) dan nilai di dalam empat kuadran atau sektor (Marimin, 2004) menjadi:

a. Sektor I (Autonomous), weak driverweak dependent, dimana elemen atau sub elemen yang masuk ke dalam sektor ini tidak berkaitan dengan sistem. 
b. Sektor II (Dependent), weak driverstrong dependent, dimana elemen atau sub elemen yang masuk ke sektor ini adalah elemen atau sub elemen yang tidak bebas.

c. Sektor III (Linkage), strong driverStrong dependent, dimana elemen atau sub elemen yang masuk ke dalam sektor ini memerlukan pengkajian yang mendalam, setiap tindakan terhadapnya akan berpengaruh pada elemen atau sub elemen lain, serta umpan baliknya dan memperbesar dampak.

d. Sektor IV (Independent), Strong driverweak dependent, dimana elemen atau subelemen yang masuk ke dalam sektor ini merupakan peubah bebas.

Prioritas konsumen dalam pengambilan keputusan untuk kategori produk dalam penelitian ini menggunakan aktivitas perubahan yang dimungkinkan berdasarkan kategori (J. P. Saxena; Sushil; Prem Vrat, 1992). Elemen yang digunakan membagi menjadi sembilan kategori produk yang dapat dilihat pada Tabel 1 . Responden yang digunakan dalam penelitian ini yang dibagi menjadi empat kelompok yaitu berdasarkan kategori usia (dewasa muda dan dewasa) seta jenis kelamin. Pembagian kategori ini dilakukan untuk memperlihatkan perbedaan prioritas pada masing-masing kategori. Penelitian ini membagi responden menjadi empat golongan yaitu milenial wanita, milenial pria, dewasa wanita, dewasa pria. Keempat kelompok ini memiliki beberapa kesamaan dan perbedaan. Pemahaman tentang motivasi dan teori-teori dasar yang memahami tentang motivasi seseorang maka aplikasi dari teori tersebut berguna untuk pengertian segmentasi pasar dan positioning produk. Motivasi dapat memiliki arah positif dan negatif, seseorang akan dapat merasakan adanya tenaga pendorong ke arah mendekati sesuatu atau menjauhi sesuatu. Beberapa ahli menyebutkan bahwa dorongan positif sebagai kebutuhan, keinginan atau hasrat dan menyebut dorongan negatif sebagai rasa takut atau keengganan. Kedua arah Motivasi ini meski terlihat sangat berbeda dari sudut kegiatan fisik, tapi pada dasarnya keduanya bermanfaat untuk memulai dan menunjang perilaku manusia (Sciffman \& Kanuk, 2010) kondisi ini sejalan dengan hasil penelitian.

\section{HASIL DAN PEMBAHASAN}

Pengelompokan konsumen di bagi berdasarkan usia dan jenis kelamin, sehingga didapatkan empat kelompok konsumen yaitu Konsumen milenial perempuan, konsumen milenial lakilaki, konsumen perempuan berusia dewasa dan konsumen laki-laki berusia dewasa dewasa. Hasil wawancara dengan batuan kuesioner terstruktur dengan para konsumen mendapatkan pola prioritas pemilihan produk yang perlu memiliki sertifikat halal. Kondisi hasil secara lengkap dapat dilihat pada gambar di bawah ini. Berikut hasil urutan prioritas yang didapatkan dari hasil penelitian.

Penelitian ini menggunakan sembilan kategori produk sebagai pilihan prioritas konsumen, kategori produk tersebut di tampilkan pada tabel di bawah ini:

Tabel 1. Kategori Produk Pilihan Konsumen

\begin{tabular}{ll} 
No. & Kategori Produk \\
\hline E.1 & Makanan \\
E.2 & Minuman \\
E.3 & Rumah makan \\
E.4 & Obat-obat bebas \\
E.5 & Perawatan Tubuh/ Kosmetik \\
E.6 & Busana \\
E.7 & Lembaga keuangan \\
E.8 & Alat rumah tangga \\
E.9 & Tujuan Perjalanan Wisata \\
\hline
\end{tabular}

Berdasarkan hasil pada Tabel 1 terlihat bahwa pola prioritas konsumen perempuan prioritas pertama ada pada produk Makanan (E1), Minuman (E2) dan Lembaga keuangan (E7). Pada kategori milenial memiliki perbedaan dengan laki-laki. Kategori makanan dan minuman, menjadi prioritas utama dari produk yang dipilih oleh milenial laki-laki. Keberadaan lembaga keuangan sebagai prioritas utama dalam pemilihan produk yang bersertifikat halal merupakan sebuah kondisi yang menarik karena tidak menjadi prioritas utama bagi konsumen milenial laki-laki. Pilihan konsumen untuk menjadi nasabah di Bank Syariah memiliki pengaruh yang kuat terhadap religiosity (Souiden \& Rani, 2015). Perbedaan prioritas ini bisa menjadikan jenis kelamin sebagai pembenda strategi pemasaran untuk produkproduk lembaga keuangan. Hasil dari struktur prioritas juga terjadi perbedaan kelompok prioritas golongan kedua, pada perempuan 
didapatkan kategori kosmetik, obat-obatan dan busana. Kelompok kedua ini merupakan kategori yang berisi produk yang dibutuhkan oleh konsumen wanita. Keberadaan kosmetik pada prioritas kedua menjadikan indikator bahwa konsumen wanita sudah memiliki kesadaran untuk memilih kosmetik yang memiliki label halal. Kondisi ini dapat dimanfaatkan oleh produsen untuk menyasar segmen perempuan milenial untuk produk kosmetik berlabel halal. Kondisi ini selaras dengan penelitian Krishnan et al., 2017 yang melihat sikap konsumen terhadap kosmetik halal yang dipengaruhi oleh keberadaan label halal untuk produk kosmetik. Perbedaan pola prioritas antara perempuan dan laki-laki dalam usia milenial menujukan pola perilaku yang lebih sederhana pada konsumen laki-laki dibandingkan perempuan, terlihat dari kategori rumah makan (E3), alat rumah tangga ( E 8), lembaga keuangan (E7), Perawatan Tubuh/ Kosmetik (E5), Obat-obat bebas (E7) dan Tujuan Perjalanan wisata (E9) berada pada kelompok yang sama yang menunjukkan tidak terdapat perbedaan prioritas pada kategori produk tersebut.

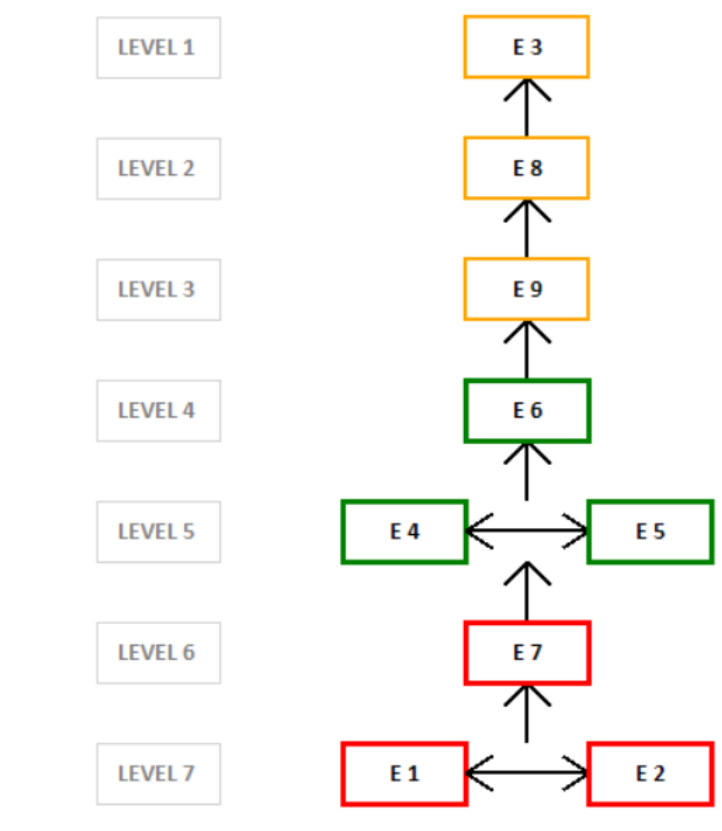

Gambar 1. Struktur Prioritas Milenial Perempuan

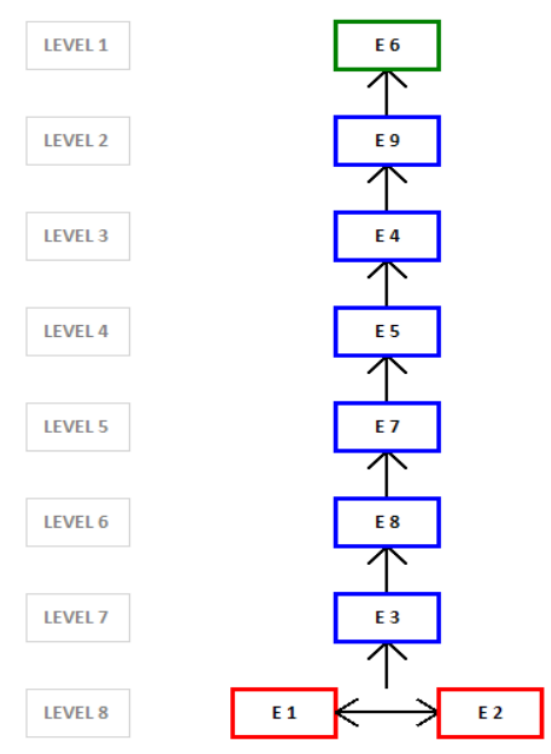

Gambar 2. Struktur Prioritas Milenial Laki-Laki

Kategori kedua pada responden milenial lakilaki adalah kosmetik, obat-obatan dan busana. Kategori kedua pada responden milenial lakilaki adalah rumah makan, alat rumah tangga, lembaga keuangan, perawatan tubuh, obat bebas dan tujuan wisata. Kategori busana adalah kategori yang memiliki prioritas terakhir. Jenis kelamin konsumen serta karakteristik konsumen memiliki pengaruh dalam pengambilan keputusan konsumen, kondisi ini sejalan dengan (Wang, Wong, \& Narayan, 2019) yang menyatakan terdapat hubungan antara karakteristik demografi pada pemilihan produk hijau.

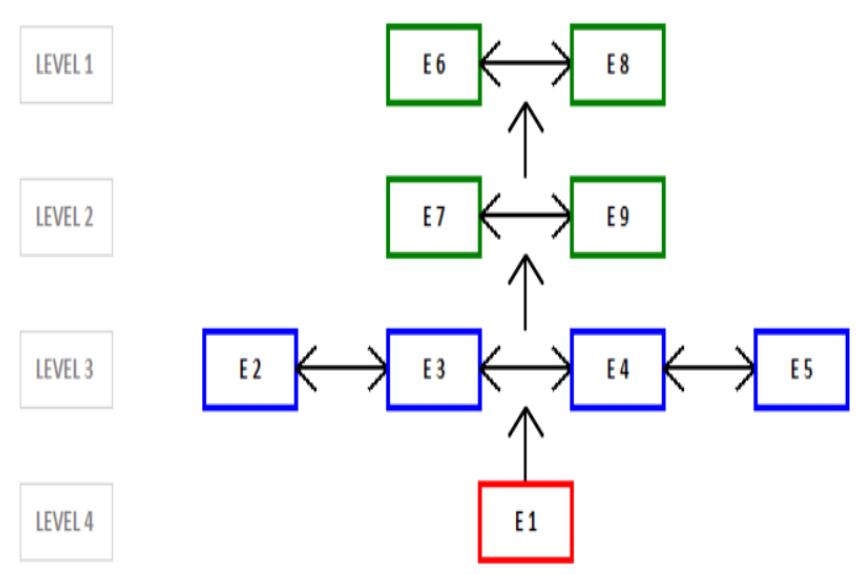

Gambar 3. Struktur Prioritas Dewasa Wanita 


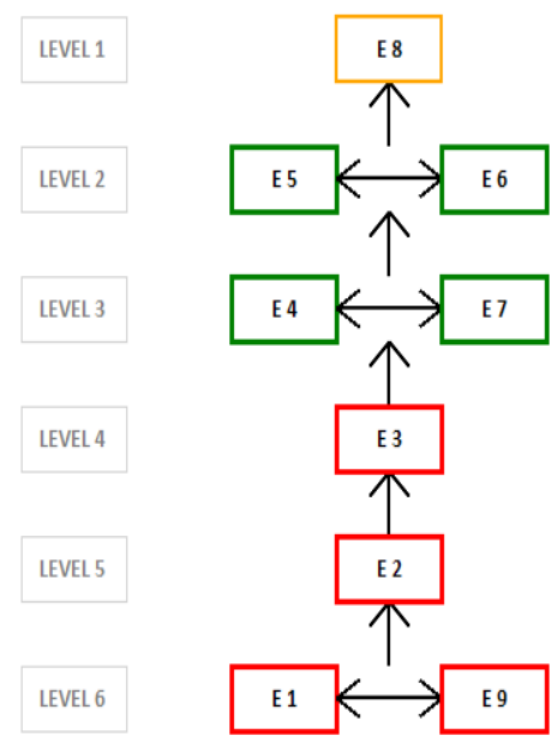

Gambar 4. Struktur Prioritas Dewasa Laki-laki

Pola pemilihan produk pada konsumen usia dewasa memilik perbedaan pada jenis kelamin. Konsumen perempuan dengan usia dewasa hanya memiliki satu kategori utama untuk produk yang memiliki label halal yaitu produk makanan. Berbeda dengan konsumen laki-laki usia dewasa yang memiliki empat kategori produk yang menjadi prioritas yaitu kategori Makanan (E1) ,pilihan tempat wisata (E9) Minuman (E2) dan rumah makan (E3). Terlihat Pada wanita dewasa makanan merupakan prioritas utama dalam kepemilikan label halal. Minuman (E2), rumah makan (E3), obat-obatan bebas(E4), lembaga keuangan (E7) dan perawatan tubuh atau kosmetik (E5) merupakan kelompok prioritas ke dua. Pada kelompok ke tiga busana menjadi prioritas terakhir. Beberapa kategori memang masih tergolong diperhatikan atau dirasa perlu oleh konsumen untuk memiliki label halal.

Pengetahuan tentang prioritas konsumen pada kategori produk yang memiliki label halal merupakan sebuah informasi penting untuk penyusunan strategi pemasaran sebuah produk. Perbedaan kategori memperlihatkan perbedaan pada kategori lembaga keuangan. Pada milenial perempuan dan dewasa laki-laki masuk dalam kategori yang cukup penting untuk memiliki kategori halal.

Produk alat rumah tangga dan busana pada saat ini mulai bermunculan produk yang memiliki sertifikat halal dan menggunakan kepemilikan sertifikat tersebut sebagai atribut yang menjadi kekuatan produk tersebut, namun dari konsumen kategori tersebut masih belum menjadi prioritas utama dari konsumen Indonesia.(Suki \& Salleh, 2018)

Makanan dan minuman tetapi menjadi prioritas utama bagi seluruh konsumen di seluruh kategori. Perjalanan wisata telah mendapat perhatian lebih dari konsumen. Perjalanan wisata yang ramah untuk muslim dapat menjadi tren selanjutnya.

\section{KESIMPULAN}

Tahapan kehidupan seorang konsumen merupakan faktor yang berkontribusi besar dalam penentuan prioritas pengambilan keputusan pemilihan produk. Berdasarkan hasil penelitian di atas terlihat bahwa terdapat perbedaan prioritas pada masing-masing kelompok responden, meskipun demikian kategori produk makanan dan minuman masih menjadi prioritas utama para konsumen dalam memilih produk yang bersertifikat halal. Perbedaan yang terjadi pada kategori berikutnya yang menjadi pembeda masing-masing kelompok. Perbedaan prioritas ini dapat dipergunakan untuk pembentukan strategi pemasaran yang sesuai dengan karakteristik demografi konsumen.

\section{REFERENSI}

Al-Kwifi, O. S., Farha, A. A., \& ahmed, Z. U. (2019). Dynamics of Muslim consumers' behavior toward Halal products: Exploration study using fMRI technology. International Journal of Emerging Markets, Volume 14 Issue 4.

Amalia, F. A., Sosianika, A., \& Suharto, D. (2020). Indonesian Millennials' Halal food purchasing: merely a habit? British Food Journal, Volume 122 Nomor 4.

Bashir, A. M. (2019). Effect of halal awareness, halal logo and attitude on foreign consumers' purchase intention. British Food Journal, Volume 121 No 9.

Chandan A. (2019). Factors Affecting Consumer Buying Behaviour. International Journal of Advanced Research (IJAR), Volume 7 No 1. 
Haque, A., Sarwar, A., Yasmin, F., Tarofder, A. K., \& Hossain, M. A. (2015). Non-Muslim consumers' perception toward purchasing halal food products in Malaysia. Journal of Islamic Marketing, Volume 6 No 1.

J. P. Saxena; Sushil; Prem Vrat. (1992). Hierarchy and classification of program plan elements using interpretive structural modeling: A case study of energy conservation in the Indian cement industry. Systems practice, 651 - 670.

Krishnan, S., Amira, N. S., Atilla, U. N., Syafawani, S., \& Hafiz, M. (2017). The Usage of Cosmetic in Malaysia: Understanding the Major Factors that Affect the Users. Management, Volume 7 Nomor 1.

Marimin. (2010). Aplikasi Teknik Pengambilan Keputusan dalam Manajemen Rantai Pasok. Bogor: IPB Press.

MUI. (2019). No Title. Retrieved from halalmui: http://www.halalmui.org/mui14/index.php/ main/go_to_section/59/1368/page/1
Niazi, M. A., Ghani, U., \& Aziz, S. (2019). Impact of Islamic Religiosity on Consumers' Attitudes towards Islamic and Conventional ways of Advertisements, Attitude towards Brands and Purchase Intentions. Business \& Economic Review, Vol 11 No 1.

Sciffman, L. G., \& Kanuk, L. L. (2010). Consumer Behaviour (10th ed). . New Jersey: Pearson Prentice Hall.

Souiden, N., \& Rani, M. (2015). Consumer attitudes and purchase intentions toward Islamic banks: the influence of religiosity. International Journal of Bank Marketing, Volume 33 No 2.

Wang, L., Wong, P. P., \& Narayan, E. A. (2019). The demographic impact of consumer green purchase intention toward Green Hotel Selection in China. Tourism and Hospitality Research, Volume 20 No 2. 